\title{
Understanding the Functional Activity of Polyphenols Using Omics-Based Approaches
}

\author{
Wenjin Si ${ }^{1,2}$, Yangdong Zhang ${ }^{3}\left(\mathbb{D}\right.$, Xiang $\mathrm{Li}^{1,2} \mathbb{D}$, Yufeng $\mathrm{Du}^{1,2}$ and Qingbiao Xu $\mathrm{X}^{1,2,3, *(\mathbb{D})}$ \\ 1 College of Animal Sciences and Technology, Huazhong Agricultural University, Wuhan 430070, China; \\ 2021302120065@webmail.hzau.edu.cn (W.S.); xxianglli@mail.hzau.edu.cn (X.L.); \\ duyufeng@webmail.hzau.edu.cn (Y.D.) \\ 2 Shennongjia Science \& Technology Innovation Center, Huazhong Agricultural University, \\ Wuhan 430070, China \\ 3 State Key Laboratory of Animal Nutrition, Institute of Animal Science, Chinese Academy of Agricultural \\ Sciences, Beijing 100193, China; zhangyangdong@caas.cn \\ * Correspondence: qbxu@mail.hzau.edu.cn
}

Citation: $\mathrm{Si}, \mathrm{W} . ;$ Zhang, Y.; Li, X.; Du, $\mathrm{Y} . ; \mathrm{Xu}, \mathrm{Q}$. Understanding the Functional Activity of Polyphenols Using Omics-Based Approaches. Nutrients 2021, 13, 3953. https:// doi.org/10.3390/nu13113953

Academic Editors: Kai Wang,

Nenad Naumovski and

Suvimol Charoensiddhi

Received: 16 September 2021

Accepted: 1 November 2021

Published: 5 November 2021

Publisher's Note: MDPI stays neutral with regard to jurisdictional claims in published maps and institutional affiliations.

Copyright: (c) 2021 by the authors. Licensee MDPI, Basel, Switzerland. This article is an open access article distributed under the terms and conditions of the Creative Commons Attribution (CC BY) license (https:/ / creativecommons.org/licenses/by/ $4.0 /)$.

\begin{abstract}
Plant polyphenols are the main category of natural active substances, and are distributed widely in vegetables, fruits, and plant-based processed foods. Polyphenols have a beneficial performance in preventing diseases and maintaining body health. However, its action mechanism has not been well understood. Foodomics is a novel method to sequence and widely used in nutrition, combining genomics, proteomics, transcriptomics, microbiome, and metabolomics. Based on multi-omics technologies, foodomics provides abundant data to study functional activities of polyphenols. In this paper, physiological functions of various polyphenols based on foodomics and microbiome was discussed, especially the anti-inflammatory and anti-tumor activities and gut microbe regulation. In conclusion, omics (including microbiomics) is a useful approach to explore the bioactive activities of polyphenols in the nutrition and health of human and animals.
\end{abstract}

Keywords: polyphenols; foodomics; functional activity; gut microbiota; multi-omics

\section{Introduction}

Plant polyphenol is a kind of secondary metabolites in plants and can enhance plant resistance and stress from disease and external environment. Generally, polyphenols are widely presented in the plant tissues (e.g., stems, roots, leaves, flowers, and fruits) as the most common plant active substances in nature [1]. Plant polyphenols have various biological activities, including anti-tumor, anti-cardiocerebrovascular, anti-oxidative, antiaging, anti-inflammatory, and anti-viral activities [2-7]. An increasing number of studies have shown that plant polyphenols play a positive role in improving animal growth performance and maintaining gastrointestinal health as antibiotics [8-11]. There is evidence that polyphenols $(1000 \mathrm{mg} / \mathrm{kg})$ can improve the intestinal morphology of yellow feather broilers, increase the body's antioxidant capacity, and improve the quality of chicken [12]. Moreover, DSS-induced colitis can be prevented and treated by honey polyphenols through regulating gut microbiota [13,14]. Therefore, polyphenols have a great potential to be a green antibiotic substitute with a beneficial effect in human and animals.

Currently, the studies on polyphenols from plant extract are mainly focused on their composition, health benefits, and metabolism $[15,16]$. The potential health benefits of plant polyphenols were confirmed by numbers of previous reports [17-19]. In a previous study, as the intake of green tea increased ( $\geq 2$ times/day), the incidence of chronic obstructive pulmonary disease dropped from $14.1 \%$ to $5.9 \%$, and it was inferred that consumption of green tea polyphenol was associated with a reduction in the risk of certain disease [20]. Another study showed that resveratrol $(10$ and $20 \mathrm{mg} / \mathrm{kg}$ ) reduced oxidative stress and inflammation. Therefore, resveratrol may be a potential therapeutic strategy for the treatment and prevention of diabetic encephalopathy [21]. Similarly, supplementing the diet 
with concentrated red grape juice $(100 \mathrm{~mL} /$ day) can reduce the plasma concentration of inflammatory biomarkers and oxidized low-density lipoproteins, and may be beneficial to reducing cardiovascular disease risk [22]. However, their metabolic pathways and regulating mechanisms have not been fully clarified. Fortunately, foodomics technology provides a novel option for investigating the functional mechanism of polyphenols $[23,24]$. Foodomics mainly consist of genomics, transcriptomics, proteomics, metabolomics, and microbiome, and foodomics has been widely used to study how to maintain gut health and normal metabolisms by regulating gut microbiota with the influence of polyphenols [25].

Recent years, mono-omics was used widely in polyphenol research. However, owing to its own limitations, mono-omics cannot fully and systematically explain the action mechanism of polyphenols. Foodomics has the advantages of diversity, relevance, and systematicity in multi-omics. For exploring and developing new insights in the molecular mechanisms of novel biomarkers, foodomics is used to analyze the biological activity of the effective compounds in food. Therefore, foodomics is an inevitable trend in the development of polyphenol study. In this review, the strategies of foodomics were discussed in investigating the activity of polyphenols and the action mechanisms and application of polyphenols.

\section{Classification, Source and Function of Polyphenols}

More than 8000 phenolic substances are commonly distributed in fruits, vegetables, tea, coffee, cocoa, beans, and grains (Table 1) [26]. Polyphenols have complex structures and can be divided into phenolic acids, lignans, stilbene, tannins, and flavonoids (e.g., isoflavones and anthocyanins). Polyphenols derived from various sources have many beneficial and specific therapeutic properties (Table 1). Phenolic acid has an extensive physiological activity, including anti-oxidation, scavenging free radicals, anti-ultraviolet radiation, and antibacterial and antiviral effects. Stilbene resveratrol has a preventive effect on atherosclerosis and cancer [27]. Stilbene and flavonoids can be used to prevent and treat cardiovascular and cerebrovascular diseases [28-30]. As the most common phytoestrogens, lignans are famous for its high anti-oxidant activity and inhibiting lipid peroxidation [31,32]. Lignans can also bind to estrogen receptors and interfere with cancer-promoting effects; therefore, it has a preventive effect on breast and colon cancer. As a kind of polyphenols, tannin can exert various activities, such as anti-oxidative, anti-microbial, anti-cancer, antihypertensive, and anti-inflammatory effects $[33,34]$. However, complexes can be formed by polyphenols with starch, protein, and enzymes; therefore, they are considered as antinutrients. Due to their carcinogenic and anti-nutritional effects, it is harmful for human and animal to have too many tannins [35].

Due to their extensive biological activities, plant polyphenols have become a study hotspot in the field of human nutrition and health. Similarly, polyphenols also have various positive effects on livestock and poultry. Plant polyphenol extracts and polyphenol monomer compounds can effectively improve animal intestinal microenvironment with various functional activities, such as immune regulation, bacteriostasis, anti-oxidation, and microbiota regulation $[36,37]$. 
Table 1. Classification, sources, and functions of polyphenols.

\begin{tabular}{|c|c|c|c|c|}
\hline Polyphenols & Subclass & Sources & Function & Ref. \\
\hline Phenolic acids & & $\begin{array}{l}\text { Coffee, berries, kiwi, } \\
\text { apple, cherry }\end{array}$ & $\begin{array}{c}\text { Anti-inflammatory, anti-oxidant, antibacterial, } \\
\text { antiviral, antiparasitic }\end{array}$ & [38-40] \\
\hline Stilbenes & & Grapes, wine & $\begin{array}{l}\text { Anti-inflammatory, anti-oxidant, heart protection, } \\
\text { anti-cancer, anti-obesity }\end{array}$ & [41-43] \\
\hline \multirow{8}{*}{$\begin{array}{l}\text { Lignans } \\
\text { Flavonoids }\end{array}$} & & Linseed, sesame, wheat & Anti-tumor, scavenging free radicals, anti-oxidant & [44-46] \\
\hline & & & & \\
\hline & Isoflavones & Soy, miso & $\begin{array}{l}\text { Estrogenic activity, anti-inflammatory, } \\
\text { anti-obesity, anti-diabetic, anti-oxidant, } \\
\text { cholesterol lowering }\end{array}$ & [47-49] \\
\hline & Flavones & $\begin{array}{l}\text { Parsley, celery, } \\
\text { capsicum pepper }\end{array}$ & $\begin{array}{l}\text { Anti-inflammatory, anti-oxidant, regulating } \\
\text { glucose and lipid metabolism, anti-virus, } \\
\text { anti-bacterial, anti-parasitic }\end{array}$ & [50-52] \\
\hline & Flavanones & $\begin{array}{l}\text { Grapefruit, lemon, } \\
\text { oranges }\end{array}$ & $\begin{array}{c}\text { Anti-inflammatory, anti-oxidant, regulating } \\
\text { glucose and lipid metabolism, preventing liver } \\
\text { steatosis, anti-bacterial, anti-viral, anti-parasitic, } \\
\text { anti-fungal }\end{array}$ & {$[53,54]$} \\
\hline & Flavonols & $\begin{array}{l}\text { Berries, onion, broccoli, } \\
\text { leek }\end{array}$ & $\begin{array}{c}\text { Anti-inflammatory, anti-oxidant, anti-virus, } \\
\text { anti-bacterial }\end{array}$ & [55-57] \\
\hline & Flavanols & $\begin{array}{l}\text { Grapes, cocoa, wine, } \\
\text { apricots, green tea, } \\
\text { beans }\end{array}$ & $\begin{array}{l}\text { Anti-inflammatory, anti-oxidant, antibacterial, } \\
\text { antiviral, antiparasitic, anticancer }\end{array}$ & [58-60] \\
\hline & Anthocyanins & $\begin{array}{l}\text { Berries, black grapes, } \\
\text { aubergine, red wine, } \\
\text { rhubarb }\end{array}$ & $\begin{array}{c}\text { Anti-inflammatory, anti-bacterial, anti-oxidant, } \\
\text { anti-diabetic, anti-cancer, nerve protection, } \\
\text { anti-allergic }\end{array}$ & [61-63] \\
\hline \multirow[t]{2}{*}{ Tannins } & Condensed tannins & $\begin{array}{l}\text { Cocoa, chocolate, } \\
\text { apples, grapes }\end{array}$ & $\begin{array}{l}\text { Anti-oxidant, eliminating free radicals, enhancing } \\
\text { immunity, preventing cardiovascular and } \\
\text { cerebrovascular diseases, improving hypoxia }\end{array}$ & [64-66] \\
\hline & $\begin{array}{l}\text { Hydrolyzable } \\
\text { tannins }\end{array}$ & Mango, pomegranate & Anti-oxidant, anticancer, phytoestrogens activity & {$[67,68]$} \\
\hline
\end{tabular}

\section{Foodomics Applied in the Study of Polyphenols}

As shown in Figure 1, foodomics is a collection of genomics, transcriptomics, proteomics, and metabolomics, and can be used to study polyphenols from multiple angles. The data obtained from various omics will be integrated to explore the molecular mechanism and novel pathways of plant polyphenols to predict and treat diseases of human and animals.

\subsection{Genomics}

Genomics, containing genome sequencing and analysis, is used to explore the interrelationships and impacts on organisms by characterizing collectively and quantifying all genes of tissue [69]. Up to now, genome sequencing technology has developed to the third or even fourth generation with various nonnegligible advantages, such as high throughput, fast speed, and high accuracy. Besides, the sequencing technology of genomics mainly includes whole-exome sequencing, whole-genome sequencing, and DNA microarray technology. Genomics has created a precedent in the era of omics and is the foundation of foodomics. It plays a vital role in exploring the bioactivity of polyphenols via sequencing and explaining the underlying mechanism at the DNA level. To evaluate the anti-inflammatory function and targeting genes of polyphenols, macrophages were treated using polyphenols and their gene expression profile was analyzed using DNA microarrays. It was found that bilberry polyphenols can decrease the high expression level of inflammatory genes caused by lipopolysaccharide [70]. Using DNA microarray technology, polyphenols from oolong tea was found to exert anti-inflammatory effects by regulating molecular networks, such as cytokines, interleukins and interferons [71]. 


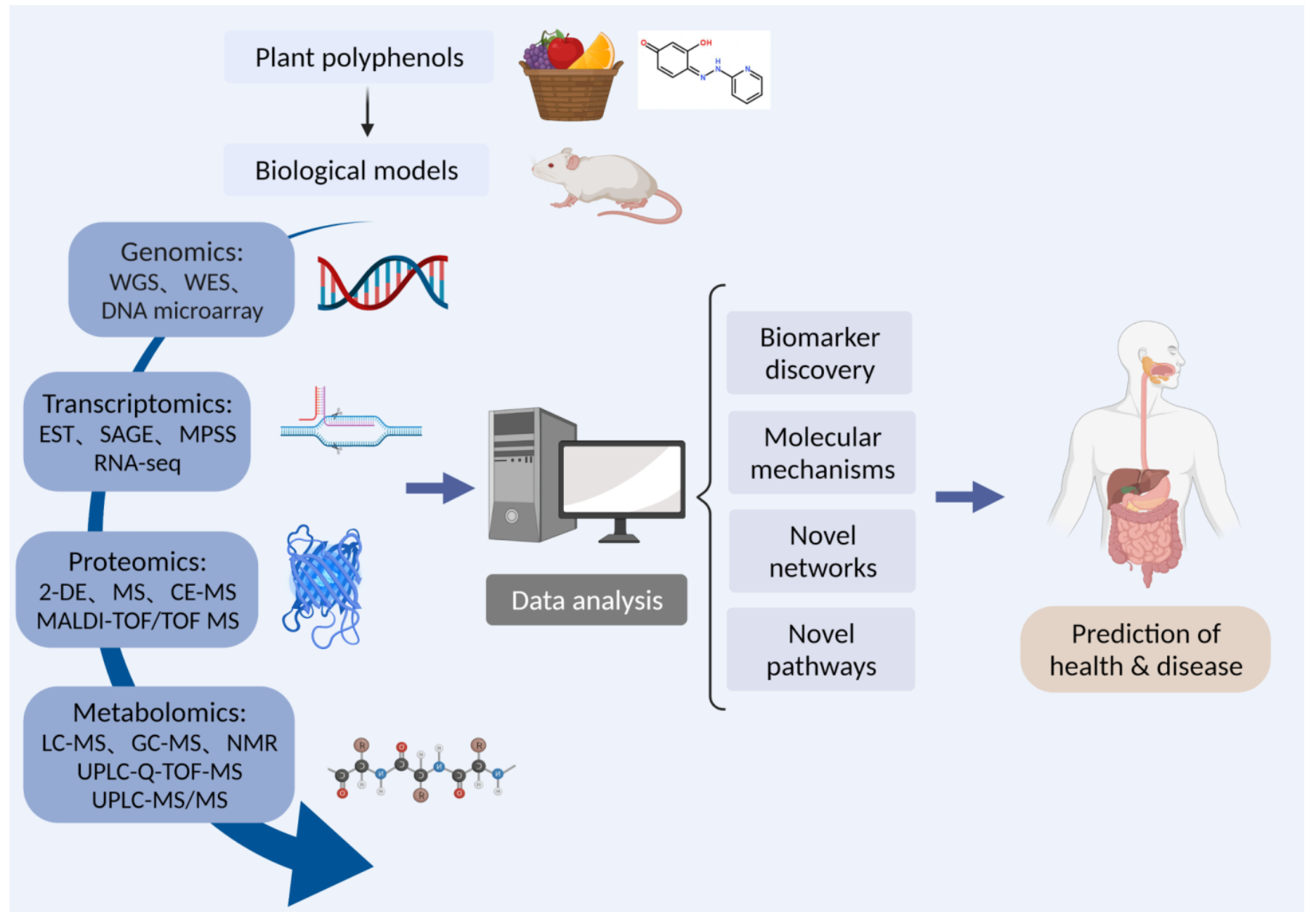

Figure 1. The strategy of foodomics to study the bioactivities of polyphenols. 2-DE: two-dimensional gel electrophoresis; CE-MS: capillary electrophoresis mass spectrometry; EST: expression sequence tags technology; GC: gas chromatography; LC: liquid chromatograph; MPSS: massively parallel signature sequencing; MALDI-TOF/TOF: matrix-assisted laser desorption ionization time-of-flight/time-of-flight; MS: mass spectrometry; NMR: nuclear magnetic resonance; RNA-seq: RNA sequencing; SAGE: serial analysis of gene expression; UPLC-Q-TOF: ultra-performance liquid chromatography to quadrupole time-of-flight; WES: whole exome sequencing; WGS: whole genome sequencing.

Genomics technology can facilitate to understand the action mechanism of polyphenols and discover novel natural polyphenols. Many genomics technologies are the effective tools for identifying polyphenol genes, including candidate gene methods, quantitative trait locus (QTL) detection, and genome-wide association studies (GWAS). As the name implies, QTL refers to the position of genes that control quantitative traits in the genome. These QTLs were detected in apples for the first time and represent a novel step in studying the biosynthesis mechanism of proanthocyanidins and the biosynthesis of phenolic compounds. It was used in the measurement of main phenolic compounds in sensory properties and main polymerization degree of proanthocyanidins in cider [72]. GWAS involve the whole-genome resequencing (WGS) of each individual in a population with rich genetic diversity. The phenotypic data of the target trait is integrated for whole-genome association analysis, which can quickly obtain chromosome segment or gene locus that affects the target trait. In a previous study, WGS data were used to perform GWAS analysis on 10 polyphenol components, unearthing key QTLs, screening specific germplasm, and discovering excellent genes. This analysis greatly accelerated the breeding process of polyphenol-rich varieties [73]. The WGS combined with bioinformatics analysis was used and discovered the five-membered angle ring polyphenols with novel structure [74]. Therefore, it can be 
concluded that the combination of GWAS and other genetic technologies represents the trend of the future research on polyphenols.

\subsection{Transcriptomics}

Transcriptome is a total number of RNA transcribed from a specific cell or tissue in a certain functional state. Transcriptomics is used to investigate the transcription conditions and transcriptional regulation rules from the overall level. The definition of time and space is the difference between the transcriptome and genome. Polyphenols can change the expression of genes in the inflammation related signal pathway, regulating the NF- $\mathrm{kB}$ signal pathways by inhibiting the activity of IKKs, preventing p50 and p65 from entering the nucleus, and enhancing the expression of a series of inflammatory cytokines (e.g., iNOS, cyclooxygenase-2 (COX-2), and cytokines) [75,76] (Figure 2). It can also regulate monophosphate-activated protein kinase (MAPK) pathway by alleviating the activity of MAPKKKs and prevent a series of transcription factors entering the nucleus to express a series of inflammatory cytokines [77]. Baicalein can decrease COX-2 expression via regulating MAPK signal pathway [78]. Similarly, quercetin can also decrease COX-2 expression through regulating the NF- $\mathrm{KB}$ signal pathway [79]. COX-2 is a kind of cyclooxygenase with very low activity in normal cells. However, when the cells are stimulated by inflammation, the expression level of COX-2 can be increased to dozens of times, causing inflammation and tissue damage. Secondly, polyphenols display an anti-oxidant function through regulating transcription factor level and activating signal channels to enhance the expression of anti-oxidant proteins. Quercetin can up-regulate the transcription level of nuclear factor erythroid-2-related factor (Nrf2), post-transcriptional level, and inhibit the post-transcriptional expression of Keap1, resulting in the enhancement of the expression of anti-oxidant proteins and detoxification enzymes [80]. Similarly, fisetin and mustard extracts can up-regulate the expression of reducing coenzyme II-quinone oxidoreductase through transcriptional activation of the Nrf2-ARE anti-oxidant pathway [81,82].

At present, transcriptomics technology mainly consists of two types: microarray based on hybridization, and transcriptome sequencing technology based on sequencing technology, which includes expression sequence tags technology, RNA sequencing, gene expression analysis, and signature sequencing. cDNA microarray-based transcriptome technology was used to illustrate the important role of microRNAs in resveratrol-mediated colon cancer associated with colitis. In detail, resveratrol can mediate anti-inflammatory properties and inhibit gut tumorigenesis via miRNA regulation [83]. In addition, the full-length transcriptome sequencing technology was combined to reveal the expression of olive polyphenol anabolism-related genes, which facilitates to understand the polyphenol biosynthesis pathway in olives [84]. Due to the characteristics of high anti-oxidant performance, good thermal stability, and natural non-toxicity, rosemary polyphenol has been widely used in health products and cardiovascular drugs. Rosemary polyphenol can regulate the metabolic and transcriptional changes in HT-29 cells dominated by the production of reactive oxygen species and the coordination of the unfolded protein response signaling pathway under endoplasmic reticulum stress using transcriptomics technology [85]. These findings indicated that transcriptomics is a useful tool to investigate the mechanism of polyphenols in cell protection and cancer chemoprevention. 


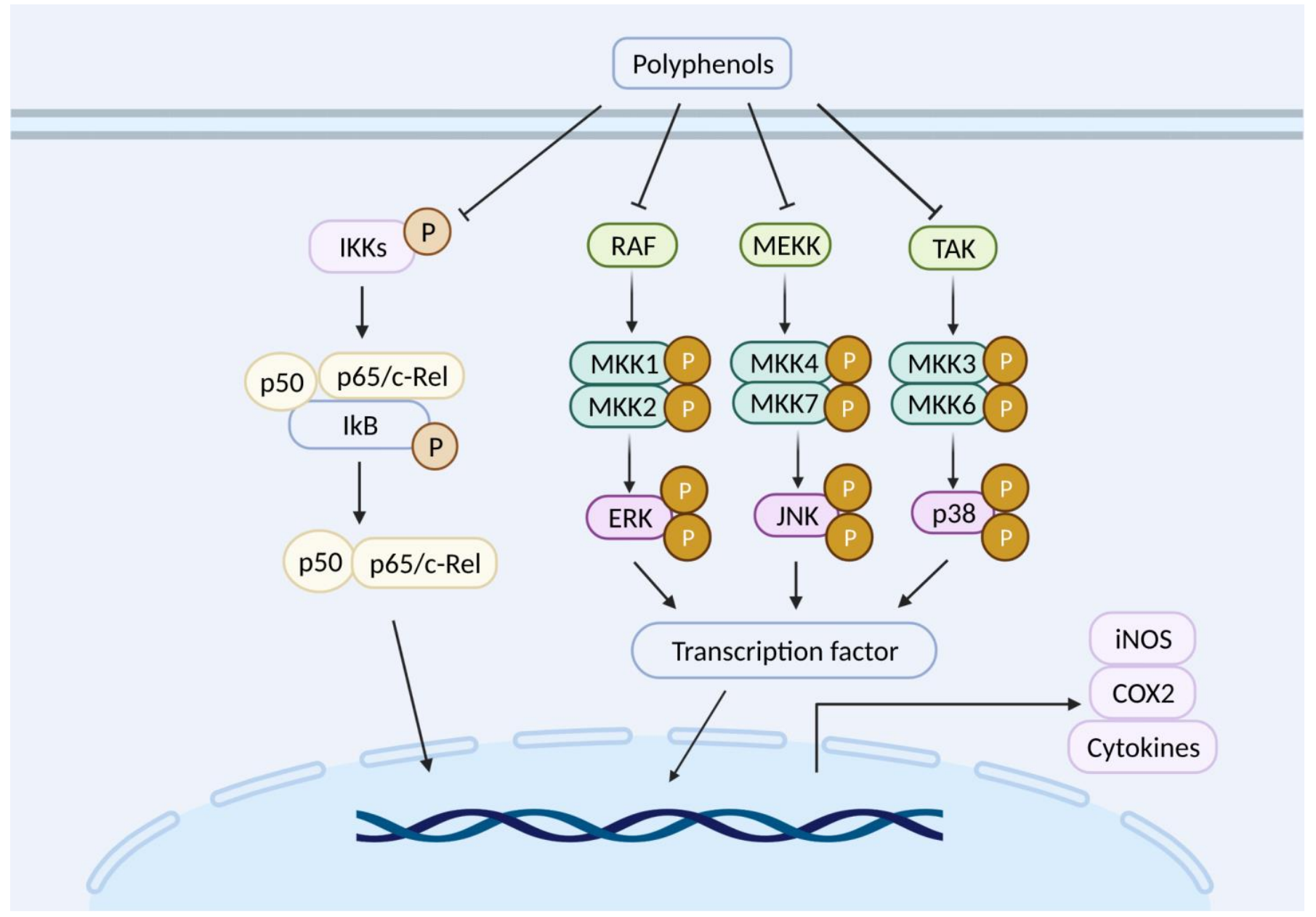

Figure 2. The potential anti-inflammatory mechanism of polyphenols. COX2: cyclooxygenase-II; ERK: extra-cellular signal regulated kinases; IKKs: IkB-kinase; iNOS: inducible nitric oxide synthase; JNK: c-Jun amino-terminal kinases; MEKK: mitogen-activated protein kinase kinase kinase; MKK: mitogen-activated protein kinase kinase; NF-kB: nuclear factor kappa-light-chain-enhancer of activated B cells; RAF: Raf kinases; TAK: Tak kinases.

\subsection{Proteomics}

Proteomics can provide systematic research on the characteristics, quantity, and function of all proteins expressed by a certain organism or cell in the treatment of plant polyphenols. Proteomics technology consists of two-dimensional gel electrophoresis (2-DE), isoelectric focusing, time-of-flight mass spectrometry (TOF-MS), electrospray mass spectrometry (ESI-MS), and capillary electrophoresis mass spectrometry [86]. As an important approach for large-scale study of cellular protein functions, proteomics is often used in revealing molecular mechanisms of tumor pathogenesis and searching for biomarkers. With the rise in proteomics technology, it has gradually become a hotspot by elucidating the anti-tumor mechanism of plant polyphenols in the perspective of protein. For example, the expression of the HSP27 protein related to the growth and apoptosis of the breast cancer cell MCF-7 was regulated by polyphenol resveratrol measured using IFE, SDS-PAGE, and ESI-MS/MS proteomics techniques [87]. The anti-tumor synergistic mechanism of curcumin and irinotecan were also investigated using proteomics approach, identifying 54 differentially expressed protein spots involved in the calcium ion, cellular respiratory chain, and redox pathway in colon cancer [88]. Through SDS-PAGE and LCMS/MS technology, it was also found that the expressions of histocompatibility antigen and $\beta$-2-microglobulin were up-regulated in myeloma cells by gossypol treatment, indicating that gossypol has the function of activating cellular immune response [89]. Through 
2-DE and MALDI-TOF/MS analysis, epigallocatechin gallate (EGCG) may activate adenine MAPK by inducing ROS production to inhibit FFA-induced lipid aggregation in human hepatocellular carcinomas (HepG2) cells, leading to inhibiting liver gluconeogenesis [90]. Seventy differential protein expression points were found in HepG2 cells after quercetin treatment through proteomics. Among them, the expression of Ras GTPase-activating-like protein involved in cell migration ability was down-regulated by quercetin, indicating that quercetin can inhibit proliferation and migration of HepG2 cells [91]. In general, proteomics provides a novel approach to explore the anti-tumor mechanism of plant polyphenols in cancer cells, including comparing and identifying the differentially expressed proteins, and clarifying the complex process and molecular mechanism.

\subsection{Metabolomics}

Metabolomics is an approach that analyzes metabolites $(<1 \mathrm{kDa})$ of human and animals after polyphenol treatment, and it is a novel "omics" technique proposed after the emergence of genomics, proteomics, and transcriptomics [92]. Genomics and proteomics tell us what might happen, while metabolomics tells us what had happened with polyphenol treatment. Metabolomics explores the relationship between metabolites and physiological changes by analyzing all metabolites in the organism, and applying liquid chromatograph-mass spectrometry (LC-MS), nuclear magnetic resonance, and gas chromatography (GC)-MS [93]. At present, the most common used analysis method is a combined instrument, such as ultra-performance liquid chromatography to quadrupole time-of-flight-MS (UPLC-Q-TOF-MS) and UPLC-MS/MS.

As a vital direction of foodomics, metabolomics technology was applied to quantify the polyphenols in food, and to target metabolic pathways to explore the molecular mechanism of metabolism (Table 2). Metabolomics has been widely used to study the physiological properties of polyphenols by detecting changes in small metabolites. The effects of green tea polyphenols on human health were explored using LC-MS and GC-MS, which led to the finding that metabolic patterns were changed, including decreased thermogenic carbohydrates as well as increased vitamin synthesis and amino acid metabolism. The variation of gut microflora-related metabolism may be the underlying mechanism of green tea polyphenols in preventing obesity [94]. Based on the metabolomics technology of high-resolution MS, the active polyphenols in litchi decreased serum triglyceride and cholesterol levels caused by a high-fat diet, confirming that litchi polyphenols have the inhibiting activity on cardiovascular disease [95]. In addition, anthocyanins in black soybean seed coats can decrease NO, PGE2, and iNOS and COX-2 expression to exert anti-inflammatory activity through metabolomics in rats [96]. The metabolomics of aging mice under the intervention of EGCG was measured using UPLC-Q-TOF-MS, showing that the metabolic pathway and metabolites was related to the anti-aging effect of EGCG [97]. UPLC-Q-TOF-MS metabolomics was used to study the gastrointestinal defense effect of polyphenol-rich bee pollen, which was found to inhibit the inflammatory response and regulate the metabolites and metabolic pathway in Caco-2 cells [98]. Although the numbers of studies have shown that plant polyphenols have various functions in vivo and vitro, in fact, the bioavailability of plant polyphenols is low [99], and their mechanism that affects health is still not fully clear. In the future, the strategy of enhancing the bioavailability of polyphenols needs to be explored. 
Table 2. Metabolomics used in identifying plant polyphenols of food.

\begin{tabular}{|c|c|c|c|}
\hline Polyphenol-Rich Foods & Polyphenols Identification & MS Based Tools & Ref. \\
\hline Strawberry & $\begin{array}{c}\text { Cyanidin, ellagic acid derivatives, glycosides of } \\
\text { quercetin, kaempferol, taxifolin } 3-O \text {-arabinoside, } \\
\text { peonidin, pelargonidin }\end{array}$ & UHPLC-HR-MS & [100] \\
\hline Blueberry & $\begin{array}{c}\text { Anthocyanins, flavonols, flavan-3-ols, resveratrol, } \\
\text { phenolic acids }\end{array}$ & HPLC-IT-TOF-MS & [101] \\
\hline Cherry & $\begin{array}{l}\text { Hydroxycinnamic acids, anthocyanins, flavonoids } \\
\text { Delphinidin-3-O-rutinoside-5-O-glucoside; }\end{array}$ & LC-ESI-Q-TOF-MS & [102] \\
\hline Berry & $\begin{array}{c}\text { 5-caffeoylquinic acid, quercetin-3-O-rutinoside, } \\
\text { quercetin-3-O-glucoside, } \\
\text { petunidin-3-O-rutinoside-5-O-glucoside, } \\
\text { 3-caffeoylquinic acid, } \\
\text { malvidin-3-O-rutinoside-5-O-glucoside, } \\
\text { 4-caffeoylquinic acid }\end{array}$ & UPLC-PDA-Q-TOF-MS & [103] \\
\hline Grape & Anthocyanins, flavan-3-ols, flavonols, stilbenes & LC-MS & [104] \\
\hline Apples & $\begin{array}{l}\text { Procyanidin, chlorogenic acid, quercetin, (+)-catechin, } \\
\qquad(-) \text {-epicatechin }\end{array}$ & UPLC/MS & [105] \\
\hline Onions & Quercetin- $4^{\prime}$-glucoside, quercetin- $3,4^{\prime}$-diglucoside & LC-MS/MS & [106] \\
\hline Cabbage & $\begin{array}{l}\text { Quercetin-3-disinapoyl-triglucoside-7-diglucoside, } \\
\text { kaempferol 3-di(tri, feruloyldi, sinapoyltri, } \\
\text { disinapoyltri)glucoside-7-diglucoside }\end{array}$ & $\begin{array}{l}\text { HPLC-DAD-ESI-MS, } \\
\text { HPLC-DAD-MS }\end{array}$ & $\begin{array}{l}{[107,} \\
108]\end{array}$ \\
\hline Beans & $\begin{array}{l}\text { Delphinidin-3-O-glucoside, cyanidin-3-O-glucoside, } \\
\text { cyanidin-3-O-sambubioside, } \\
\text { pelargonidin-3-O-glucoside, malvidin-3-O-glucoside, } \\
\text { cyanidin-3-O-galactoside, petunidin-3-O-glucoside }\end{array}$ & HPLC-ESI-MS & [109] \\
\hline Barley & $\begin{array}{c}\text { Caffeic acid, catechin, cereals, ellagic acid, ferulic acid, } \\
\text { gallic acid, isoscoparin-2"-O-glucoside, p-coumaric acid, } \\
\text { procyanidin B2 }\end{array}$ & Q-TOF-LC-MS & [110] \\
\hline Nut & $\begin{array}{c}\text { (+)-catechin, }(-) \text {-epicatechin, procatechuic acid, } \\
\text { p-hydroxybenzoic acid, quercetin-3-O-rutinoside, } \\
\text { naringenin-7-O-glucoside }\end{array}$ & LC-MS & [111] \\
\hline Cocoa beans & Flavan-3-ols, procyanidins, $(+)$-catechin, $(-)$-epicatechin & HPLC-DAD, HPLC-FL & [112] \\
\hline Coffee & Phenolic acids, flavonoids, secoiridoids & HPLC-MS/MS & [113] \\
\hline Green tea & $\begin{array}{l}\text { Quercetin-3-O-galactoside, chlorogenic acid, epicatechin, } \\
\text { epigallocatechin gallate, proanthocyanidin B2, } \\
\text { quercetin-3-O-galactoside }\end{array}$ & LC-MS & [114] \\
\hline Wine & $\begin{array}{c}\text { Gallic acid, gentisic acid, protocatechuic } \\
\text { acid-O-hexoside, protocatechuic acid, caftaric acid, } \\
\text { catechin, coumaric-O-hexoside, } p \text {-hydroxybenzoic acid, } \\
\text { caffeic acid }\end{array}$ & HPLC/ESI-LTQ-Orbitrap-MS & [115] \\
\hline
\end{tabular}

Note: ESI-LTQ-MS: electrospray ionisation-linear ion trap quadrupole-Orbitrap-mass spectrometry; HPLC-DAD-ESI-MS: high-performance liquid chromatography coupled to photodiode-array detection and electrospray ionization/ion trap mass spectrometry; IT-TOF: ion trap with time-of-flight; Q-TOF-MS: quadrupole-time of flight; UPLC-Q-TOF-MS: ultra-performance liquid chromatography-quadrupole-time of flight-mass spectrometry; UHPLC-HR: UPLC-high-resolution.

\subsection{Multi-Omics}

Omics has a great contribution to the study of the action mechanism of polyphenols. However, the information obtained from the previous reports at a certain level (genome, transcriptome, and proteome) has certain limitations. Therefore, multiple omics should be combined to make correlations from a holistic perspective to systematically elucidate the functions and mechanisms of polyphenols. The regulation of R2R3-MYBs transcription factor is the key to control the synthesis of flavonoids in angiosperms using the combination of metabolome and transcriptome [116-118]. Based on multi-omics technology, highpolymer proanthocyanidins was found to reduce the level of metabolites, influence the intestinal microbial community, and have a beneficial effect on metabolic homeostasis [119]. By using 2-DE and MALDI-TOF/MS analysis, EGCG can decrease cell apoptosis and inhibit metastasis of human liver cancer cells [120]. Similarly, it was revealed that resveratrol can regulate the cell cycle of colon cancer cell using SDS-PAGE and LC-MS/MS analysis [121]. 
In conclusion, multi-omics is a useful approach in the study of the functional activity of plant polyphenols.

\section{Microbiomics Involved in the Bioactivity of Polyphenols}

\subsection{Regulation of Polyphenols on Gut Microbiota}

Microbiome refers to all microorganisms and genetic information in a specific environment and has beneficial effects in nutrition, metabolism, and immunity [122]. Gut microbiota mainly consists of Actinobacteria, Bacteroidetes, Firmicutes, Fusobacteria, Proteobacteria, and Verrucomicrobia. Among them, Firmicutes and Bacteroides are the dominant microbiota [123]. Like prebiotics, the polyphenols in diet have received widespread attention for their functional regulatory effects on gut microorganisms, as shown in Figure 3. Polyphenols can inhibit harmful bacteria proliferation (e.g., Escherichia coli and Salmonella), while promoting the growth of probiotics (e.g., Bifidobacterium and Lactobacillus).

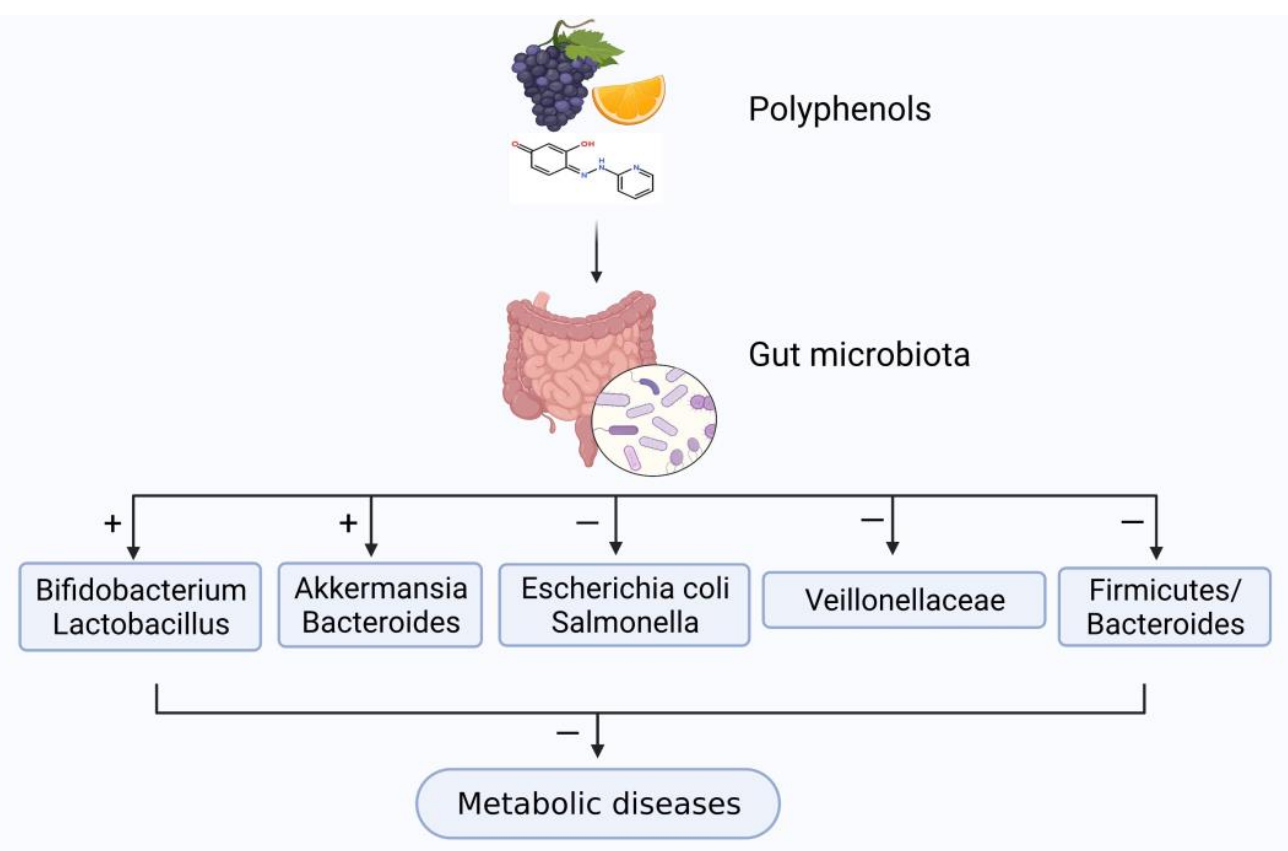

Figure 3. The influence of the interaction between plant polyphenols and gut microbiota on metabolic diseases. "+" means "enhance"; "-" means "weaken".

Intestinal disorders can be inhibited by polyphenols via richening the abundance of beneficial bacteria and microbial diversity. Resveratrol has a promoting effect on Lactobacillus and Bifidobacterium, which can exert anti-inflammatory effects through reducing pro-inflammatory cytokines and increasing anti-inflammatory cytokines [124,125]. Alpha diversity of gut microbiota was changed, and relative abundances of Bifidobacterium, Feacalibacterium, Eubacterium, and Coprococcus were increased by the intake of polyphenols from green tea [126]. The abundance of Bifidobacteria and Lactobacillus in the gut were increased by the intake of blueberries [127]. In addition, it has been confirmed that inflammatory bowel disease (IBD) is influenced by multiple factors, including the host, microorganisms, and the environment, and the occurrence of IBD is related to gut microbes [128]. In our lab, we found that polyphenol taxifolin changed the composition of colonic microbial community by $16 \mathrm{~S}$ rDNA sequencing. The change in Bacteroides, Clostridium saccharogumia, Clostridium ramosum, Sphingobacterium multivorum, and Bacteroidetes / Firmicutes ratio caused by dextran sulfate sodium was restored by taxifolin to relieve mice colitis [129]. In conclusion, plant polyphenols can promote beneficial bacteria in the process of regulating 
intestinal microbes. Once the polyphenols enter the intestinal tract, they will activate the gut microbiota and regulate gut microecology. Conversely, polyphenols can also be used by gut microbiota to produce bioactive molecules (e.g., phenolic acids), which may be the key biologically active effector $[130,131]$, subsequently promoting the health of human and animals.

\subsection{Combination of Microbiome and Metabolomics in Polyphenol Study}

Currently, microbiome technologies mainly contain microbial metagenomics, metametabolomics, macrotranscriptomics, and macroproteomics, allowing us to analyze the microbiome at different levels (e.g., DNA, RNA, protein, and metabolites). At present, numbers of studies on polyphenols mainly focus on metagenomics and metametabolomics. In contrast, their combination to explore the metabolic process of polyphenols is still lacking. The combination of metabolomics and microbiome is a novel approach to explore the specific mechanism of polyphenols. Gut microbiota plays a critical role in health and nutritional status of human and animals [132]. In general, the method of the combination of microbiome and metabolomics is shown in Figure 4. By sequencing the metagenomics of gut microbiota, the corresponding microorganisms can be identified and metabolites can be analyzed using metabolomics technology to discover a novel pathway. In a previous study, primary bile acids were modified into secondary bile acids by clostridium species using $16 \mathrm{~S}$ amplicon sequencing and metabolomics [133]. It has been verified that polyphenols have various biological activities with a positive influences on gut microbes [134-136]. Therefore, the combination of metabolomics and microbiome in the exploration of polyphenols is a trend in the future.

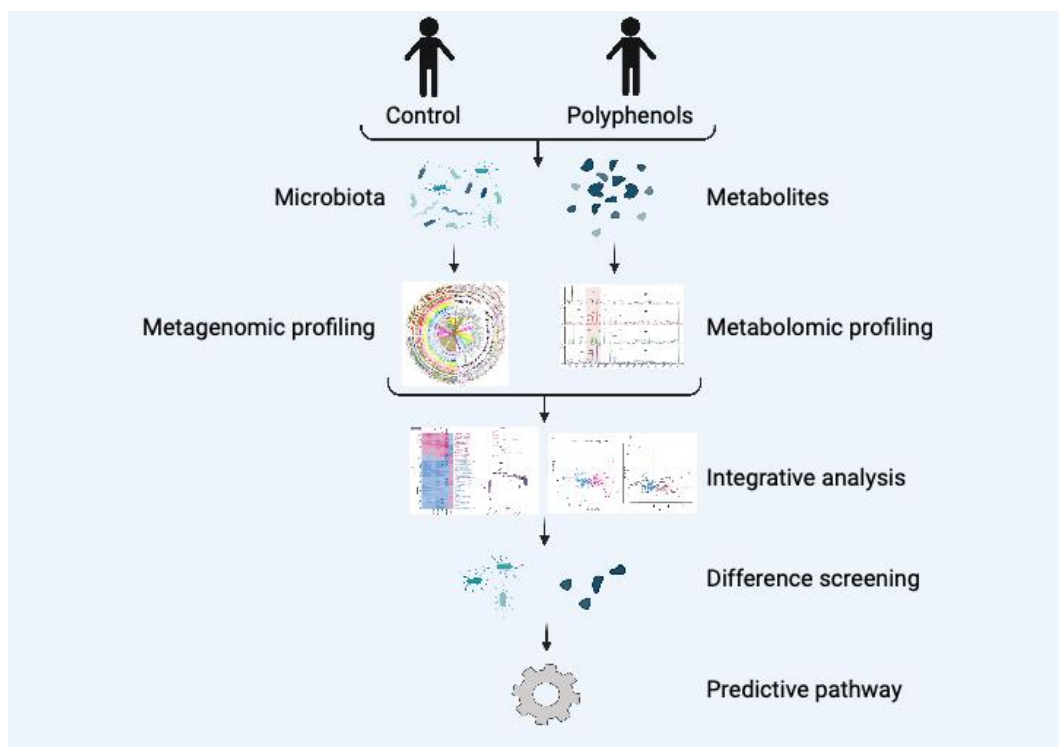

Figure 4. Combining microbiome and metabolomics to investigate the bioactivity of plant polyphenols.

The combination of microbiome and metabolomics has been used to study the effects of plant polyphenols on cardiovascular diseases. Through the metabolomics and genomics analysis of microorganisms in serum, urine, and feces, the risk of cardiovascular disease can be reduced by pomegranate polyphenols [137]. The influence of green tea polyphenols on gut microbiota and micronutrient metabolism was analyzed using metagenomics and metabolomics, and the metabolites of tricarboxylic acid and urea cycle were analyzed using metabolomics and 16S rRNA sequencing, showing that energy conversion was enhanced by green tea polyphenols via promoting the metabolism of gut microbiota in rat [138]. Moreover, the diversity and overall structure of gut microbiota were changed by polyphenols using $16 \mathrm{~S}$ rRNA sequencing, indicating that polyphenols have an anti- 
cancer effect. Therefore, it has been speculated that polyphenols can regulate tumor growth by controlling certain bacteria and subsequently changing the cellular components and metabolites [139]. In conclusion, the positive effects of polyphenols on human gut health can be clarified through a microbiome approach. The underlying mechanisms of polyphenols on gut microbiota and metabolites using microbiomics, metabolomics, and multiple omics need to be further explored.

\section{Conclusions and Further Perspective}

In summary, polyphenols are widely distributed in our diet, which mainly come from vegetables and fruits. It has anti-inflammatory, anti-oxidation, anti-tumor, and gut health protection properties. Foodomics (genomics, transcriptomics, proteomics, metabolomics, and multi-omics) emphasized the remarkable efficacy of polyphenols in preventing and treating diseases, especially the anti-inflammatory and anti-tumor activity and gut microbiota regulation. Gut microbes are involved in the metabolic processes of polyphenols. Foodomics and microbiomics have contributed to the study of the mechanism of polyphenols.

With the continuous development of omics technology, integrated analysis technology of omics and multi-omics will help to explore the biological activity and gut microbiota regulation of plant polyphenols. However, the bioactivity, metabolism, and mechanism of polyphenols have not been fully understood. Due to the physical and chemical stability, chelation, food interaction, and gastrointestinal absorption and metabolism, the bioavailability of polyphenols is still low in the body of human and animals. Therefore, it is necessary to combine multiple omics technologies to investigate the biological function mechanism of plant polyphenols in the future. The strategy of enhancing the bioavailability of polyphenols also needs to be further explored. The combined analysis of foodomics and microbiomics is a trend of polyphenol research.

Author Contributions: Design, W.S. and Q.X.; investigation, W.S.; writing, W.S. and Y.D.; review and editing, Y.Z., X.L., Y.D. and Q.X.; supervision, Q.X.; funding acquisition, X.L., Y.D. and Q.X., W.S., Y.Z. and X.L. contributed equally to this work. All authors have read and agreed to the published version of the manuscript.

Funding: This work was funded by the State Key Laboratory of Animal Nutrition (2004DA125184F1906), the Key Laboratory of Molecular Animal Nutrition of Zhejiang University, the Fundamental Research Funds for the Central Universities (2662019QD021), and the Open Project Program of Key Laboratory of Feed Biotechnology.

Institutional Review Board Statement: Not applicable.

Informed Consent Statement: Not applicable.

Data Availability Statement: Not applicable.

Acknowledgments: We are grateful to the review participants.

Conflicts of Interest: The authors declare no conflict of interest.

\section{References}

1. Quideau, S.; Deffieux, D.; Douat-Casassus, C.; Pouysegu, L. Plant polyphenols: Chemical properties, biological activities, and synthesis. Angew. Chem. Int. Ed. 2011, 50, 586-621. [CrossRef]

2. An, J.; Hao, D.; Zhang, Q.; Chen, B.; Zhang, R.; Wang, Y.; Yang, H. Natural products for treatment of bone erosive diseases: The effects and mechanisms on inhibiting osteoclastogenesis and bone resorption. Int. Immunopharmacol. 2016, 36, 118-131. [CrossRef]

3. Ben Mansour, R.; Wided, M.K.; Cluzet, S.; Krisa, S.; Richard, T.; Ksouri, R. LC-MS identification and preparative HPLC isolation of Frankenia pulverulenta phenolics with antioxidant and neuroprotective capacities in PC12 cell line. Pharm. Biol. 2017, 55, 880-887. [CrossRef]

4. Omodanisi, E.I.; Aboua, Y.G.; Oguntibeju, O.O. Assessment of the anti-hyperglycaemic, anti-inflammatory and antioxidant activities of the methanol extract of moringa oleifera in diabetes-induced nephrotoxic male wistar rats. Molecules 2017, 22, 439. [CrossRef] 
5. Nagulapalli Venkata, K.C.; Swaroop, A.; Bagchi, D.; Bishayee, A. A small plant with big benefits: Fenugreek (Trigonella foenumGraecum Linn.) for disease prevention and health promotion. Mol. Nutr. Food Res. 2017, 61, 1600950. [CrossRef]

6. $\quad$ Odongo, G.A.; Schlotz, N.; Herz, C.; Hanschen, F.S.; Baldermann, S.; Neugart, S.; Trierweiler, B.; Frommherz, L.; Franz, C.M.A.P.; Ngwene, B.; et al. The role of plant processing for the cancer preventive potential of Ethiopian kale (Brassica carinata). Food Nutr. Res. 2017, 61, 1271527. [CrossRef]

7. Miyamoto, T.; Zhang, X.; Ueyama, Y.; Apisada, K.; Nakayama, M.; Suzuki, Y.; Ozawa, T.; Mitani, A.; Shigemune, N.; Shimatani, K.; et al. Development of novel monoclonal antibodies directed against catechins for investigation of antibacterial mechanism of catechins. J. Microbiol. Methods 2017, 137, 6-13. [CrossRef]

8. Surai, P.F. Polyphenol compounds in the chicken/animal diet: From the past to the future. J. Anim. Physiol. Anim. Nutr. 2014, 98, 19-31. [CrossRef]

9. Scicutella, F.; Mannelli, F.; Daghio, M.; Viti, C.; Buccioni, A. Polyphenols and organic acids as alternatives to antimicrobials in poultry rearing: A review. Antibiotics 2021, 10, 1010. [CrossRef]

10. Huang, Q.; Liu, X.; Zhao, G.; Hu, T.; Wang, Y. Potential and challenges of tannins as an alternative to in-feed antibiotics for farm animal production. Anim. Nutr. 2018, 4, 137-150. [CrossRef]

11. Gessner, D.K.; Ringseis, R.; Eder, K. Potential of plant polyphenols to combat oxidative stress and inflammatory processes in farm animals. J. Anim. Physiol. Anim. Nutr. 2017, 101, 605-628. [CrossRef]

12. Effects of Botanical Polyphenol on Antioxidant Capacity, Intestinal Morphology and Meat Quality of Yellow Broilers-All Databases Available online: https:/ / www.webofscience.com/wos/alldb/full-record/CSCD:6423241 (accessed on 29 October 2021).

13. Wang, K.; Wan, Z.; Ou, A.; Liang, X.; Guo, X.; Zhang, Z.; Wu, L.; Xue, X. Monofloral honey from a medical plant, prunella vulgaris, protected against dextran sulfate sodium-induced ulcerative colitis via modulating gut microbial populations in rats. Food Funct. 2019, 10, 3828-3838. [CrossRef]

14. Wang, K.; Jin, X.; Li, Q.; Sawaya, A.C.H.F.; le Leu, R.K.; Conlon, M.A.; Wu, L.; Hu, F. Propolis from different geographic origins decreases intestinal inflammation and Bacteroides Spp. Populations in a model of DSS-induced colitis. Mol. Nutr. Food Res. 2018, 62, 1800080. [CrossRef] [PubMed]

15. Saura-Calixto, F.; Serrano, J.; Goni, I. Intake and bioaccessibility of total polyphenols in a whole diet. Food Chem. 2007, 101, 492-501. [CrossRef]

16. Li, A.-N.; Li, S.; Zhang, Y.-J.; Xu, X.-R.; Chen, Y.-M.; Li, H.-B. Resources and biological activities of natural polyphenols. Nutrients 2014, 6, 6020-6047. [CrossRef] [PubMed]

17. Lee, M.T.; Lin, W.C.; Yu, B.; Lee, T.T. Antioxidant Capacity of phytochemicals and their potential effects on oxidative status in animals-A review. Asian Australas. J. Anim. Sci. 2017, 30, 299-308. [CrossRef] [PubMed]

18. Cardona, F.; Andrés-Lacueva, C.; Tulipani, S.; Tinahones, F.J.; Queipo-Ortuño, M.I. Benefits of polyphenols on gut microbiota and implications in human health. J. Nutr. Biochem. 2013, 24, 1415-1422. [CrossRef] [PubMed]

19. Bhandarkar, N.S.; Brown, L.; Panchal, S.K. Chlorogenic acid attenuates high-carbohydrate, high-fat diet-induced cardiovascular, liver, and metabolic changes in rats. Nutr. Res. 2019, 62, 78-88. [CrossRef] [PubMed]

20. Cm, O.; Ih, O.; Bk, C.; Ty, Y.; Jm, C.J.H. Consuming green tea at least twice each day is associated with reduced odds of chronic obstructive lung disease in middle-aged and older korean adults. J. Nutr. 2018, 148, 70-76. [CrossRef]

21. Tian, X.; Liu, Y.; Ren, G.; Yin, L.; Liang, X.; Geng, T.; Dang, H.; An, R. Resveratrol limits diabetes-associated cognitive decline in rats by preventing oxidative stress and inflammation and modulating hippocampal structural synaptic plasticity. Brain Res. 2016, 1650, 1-9. [CrossRef]

22. Castilla, P.; Echarri, R.; Dávalos, A.; Cerrato, F.; Ortega, H.; Teruel, J.L.; Lucas, M.F.; Gómez-Coronado, D.; Ortuño, J.; Lasunción, M.A. Concentrated red grape juice exerts antioxidant, hypolipidemic, and antiinflammatory effects in both hemodialysis patients and healthy subjects. Am. J. Clin. Nutr. 2006, 84, 252-262. [CrossRef]

23. Yang, F.; Xie, C.; Li, J.; Ma, R.; Dang, Z.; Wang, C.; Wang, T. Foodomics technology: Promising analytical methods of functional activities of plant polyphenols. Eur. Food Res. Technol. 2021, 247, 2129-2142. [CrossRef]

24. Mondello, L. Foodomics-Advanced Mass Spectrometry in Modern Food Science and Nutrition; Cifuentes, A., Ed.; John Wiley \& Sons Inc.: Hoboken, NJ, USA, 2013; 580p, ISBN 978-1-118-16945-2.

25. Andjelkovic, U.; Gajdosik, M.S.; Gaso-Sokac, D.; Martinovic, T.; Josic, D. Foodomics and food safety: Where we are. Food Technol. Biotechnol. 2017, 55, 290-307. [CrossRef] [PubMed]

26. Ganesan, K.; Xu, B. A critical review on polyphenols and health benefits of black soybeans. Nutrients 2017, 9, 455. [CrossRef]

27. Fukao, H.; Ijiri, Y.; Miura, M.; Hashimoto, M.; Yamashita, T.; Fukunaga, C.; Oiwa, K.; Kawai, Y.; Suwa, M.; Yamamoto, J. Effect of trans-resveratrol on the thrombogenicity and atherogenicity in apolipoprotein e-deficient and low-density lipoprotein receptor-deficient mice. Blood Coagul. Fibrinolysis 2004, 15, 441-446. [CrossRef] [PubMed]

28. Mahmoud, A.M.; Bautista, R.J.H.; Sandhu, M.A.; Hussein, O.E. Beneficial effects of citrus flavonoids on cardiovascular and metabolic health. Oxidative Med. Cell. Longev. 2019, 2019, 5484138. [CrossRef]

29. Vallance, T.M.; Ravishankar, D.; Albadawi, D.A.I.; Osborn, H.M.I.; Vaiyapuri, S. Synthetic flavonoids as novel modulators of platelet function and thrombosis. IJMS 2019, 20, 3106. [CrossRef]

30. Ciumărnean, L.; Milaciu, M.V.; Runcan, O.; Vesa Ștefan, C.; Răchișan, A.L.; Negrean, V.; Perné, M.-G.; Donca, V.I.; Alexescu, T.-G.; Para, I.; et al. The effects of flavonoids in cardiovascular diseases. Molecules 2020, 25, 4320. [CrossRef] 
31. Owen, R.W.; Giacosa, A.; Hull, W.E.; Haubner, R.; Spiegelhalder, B.; Bartsch, H. The antioxidant/anticancer potential of phenolic compounds isolated from olive oil. Eur. J. Cancer 2000, 36, 1235-1247. [CrossRef]

32. Owen, R.W.; Mier, W.; Giacosa, A.; Hull, W.E.; Spiegelhalder, B.; Bartsch, H. Identification of lignans as major components in the phenolic fraction of olive oil. Clin. Chem. 2000, 46, 976-988. [CrossRef]

33. Okuda, T.; Ito, H. Tannins of Constant structure in medicinal and food plants-hydrolyzable tannins and polyphenols related to tannins. Molecules 2011, 16, 2191-2217. [CrossRef]

34. Koleckar, V.; Kubikova, K.; Rehakova, Z.; Kuca, K.; Jun, D.; Jahodar, L.; Opletal, L. Condensed and hydrolysable tannins as antioxidants influencing the health. Mini Rev. Med. Chem. 2008, 8, 436-447. [CrossRef] [PubMed]

35. Chung, K.-T.; Wong, T.Y.; Wei, C.-I.; Huang, Y.-W.; Lin, Y. Tannins and human health: A review. Crit. Rev. Food Sci. Nutr. 1998, 38, 421-464. [CrossRef]

36. Theodorou, M.K.; Kingston-Smith, A.H.; Winters, A.L.; Lee, M.R.F.; Minchin, F.R.; Morris, P.; MacRae, J. Polyphenols and their influence on gut function and health in ruminants: A review. Environ. Chem. Lett. 2006, 4, 121-126. [CrossRef]

37. Geng, D.; Fang, M.Y.; Deli, L.I.; Zheng, S.Q.; Lijun, D.U. Research progress in terms of interaction between chinese medicine components and intestinal microenvironment. Sci. Sin. 2018, 48, 379-389. [CrossRef]

38. Bento-Silva, A.; Koistinen, V.M.; Mena, P.; Bronze, M.R.; Hanhineva, K.; Sahlstrøm, S.; Kitrytė, V.; Moco, S.; Aura, A.-M. Factors affecting intake, metabolism and health benefits of phenolic acids: Do we understand individual variability? Eur. J. Nutr. 2020, 59, 1275-1293. [CrossRef]

39. De Camargo, A.C.; Regitano-d'Arce, M.A.B.; Rasera, G.B.; Canniatti-Brazaca, S.G.; do Prado-Silva, L.; Alvarenga, V.O.; Sant'Ana, A.S.; Shahidi, F. Phenolic acids and flavonoids of peanut by-products: Antioxidant capacity and antimicrobial effects. Food Chem. 2017, 237, 538-544. [CrossRef]

40. Szwajgier, D.; Borowiec, K.; Pustelniak, K. The neuroprotective effects of phenolic acids: Molecular mechanism of action. Nutrients 2017, 9, 477. [CrossRef] [PubMed]

41. Berman, A.Y.; Motechin, R.A.; Wiesenfeld, M.Y.; Holz, M.K. The therapeutic potential of resveratrol: A review of clinical trials. NPJ Precis. Oncol. 2017, 1, 35. [CrossRef]

42. Cheng, C.K.; Luo, J.-Y.; Lau, C.W.; Chen, Z.-Y.; Tian, X.Y.; Huang, Y. Pharmacological basis and new insights of resveratrol action in the cardiovascular system. Br. J. Pharmacol. 2020, 177, 1258-1277. [CrossRef]

43. Varoni, E.M.; lo Faro, A.F.; Sharifi-Rad, J.; Iriti, M. Anticancer molecular mechanisms of resveratrol. Front. Nutr. $2016,3,8$. [CrossRef] [PubMed]

44. Senizza, A.; Rocchetti, G.; Mosele, J.I.; Patrone, V.; Callegari, M.L.; Morelli, L.; Lucini, L. Lignans and gut microbiota: An interplay revealing potential health implications. Molecules 2020, 25, 5709. [CrossRef]

45. Cui, Q.; Du, R.; Liu, M.; Rong, L. Lignans and their derivatives from plants as antivirals. Molecules 2020, 25, 183. [CrossRef] [PubMed]

46. Rodríguez-García, C.; Sánchez-Quesada, C.; Toledo, E.; Delgado-Rodríguez, M.; Gaforio, J. Naturally lignan-rich foods: A dietary tool for health promotion? Molecules 2019, 24, 917. [CrossRef] [PubMed]

47. Yu, J.; Bi, X.; Yu, B.; Chen, D. Isoflavones: Anti-inflammatory benefit and possible caveats. Nutrients 2016, 8, 361. [CrossRef] [PubMed]

48. Zaheer, K.; Akhtar, M.H. An updated review of dietary isoflavones: Nutrition, processing, bioavailability and impacts on human health. Crit. Rev. Food Sci. Nutr. 2017, 57, 1280-1293. [CrossRef] [PubMed]

49. Umeno, A.; Horie, M.; Murotomi, K.; Nakajima, Y.; Yoshida, Y. Antioxidative and antidiabetic effects of natural polyphenols and isoflavones. Molecules 2016, 21, 708. [CrossRef]

50. Hostetler, G.L.; Ralston, R.A.; Schwartz, S.J. Flavones: Food sources, bioavailability, metabolism, and bioactivity. Adv. Nutr. 2017, 8, 423-435. [CrossRef]

51. Kilani-Jaziri, S.; Mustapha, N.; Mokdad-Bzeouich, I.; El Gueder, D.; Ghedira, K.; Ghedira-Chekir, L. Flavones induce immunomodulatory and anti-inflammatory effects by activating cellular anti-oxidant activity: A structure-activity relationship study. Tumor Biol. 2016, 37, 6571-6579. [CrossRef]

52. Jiang, N.; Doseff, A.I.; Grotewold, E. Flavones: From biosynthesis to health benefits. Plants 2016, 5, 27. [CrossRef]

53. Barreca, D.; Gattuso, G.; Bellocco, E.; Calderaro, A.; Trombetta, D.; Smeriglio, A.; Lagana, G.; Daglia, M.; Meneghini, S.; Nabavi, S.M. Flavanones: Citrus phytochemical with health-promoting properties. Biofactors 2017, 43, 495-506. [CrossRef] [PubMed]

54. Testai, L.; Calderone, V. Nutraceutical value of citrus flavanones and their implications in cardiovascular disease. Nutrients 2017, 9, 502. [CrossRef] [PubMed]

55. Martinez, V.; Mestre, T.C.; Rubio, F.; Girones-Vilaplana, A.; Moreno, D.A.; Mittler, R.; Rivero, R.M. Accumulation of flavonols over hydroxycinnamic acids favors oxidative damage protection under abiotic stress. Front. Plant Sci. 2016, 7, 838. [CrossRef] [PubMed]

56. Scarano, A.; Butelli, E.; de Santis, S.; Cavalcanti, E.; Hill, L.; de Angelis, M.; Giovinazzo, G.; Chieppa, M.; Martin, C.; Santino, A. Combined dietary anthocyanins, flavonols, and stilbenoids alleviate inflammatory bowel disease symptoms in mice. Front. Nutr. 2018, 4, 75. [CrossRef] [PubMed]

57. Aherne, S.A.; O'Brien, N.M. Dietary flavonols: Chemistry, food content, and metabolism. Nutrition 2002, 18, 75-81. [CrossRef] 
58. Mena, P.; Bresciani, L.; Brindani, N.; Ludwig, I.A.; Pereira-Caro, G.; Angelino, D.; Llorach, R.; Calani, L.; Brighenti, F.; Clifford, M.N.; et al. Phenyl- $\gamma$-valerolactones and phenylvaleric acids, the main colonic metabolites of flavan-3-ols: Synthesis, analysis, bioavailability, and bioactivity. Nat. Prod. Rep. 2019, 36, 714-752. [CrossRef]

59. Mena, P.; Dolores, G.; Brindani, N.; Esteban-Fernández, A.; Curti, C.; Moreno-Arribas, M.V.; Rio, D.D.; Bartolomé, B. 5-(3' ,4' dihydroxyphenyl)- $\gamma$-valerolactone and its sulphate conjugates, representative circulating metabolites of flavan-3-ols, exhibit anti-adhesive activity against uropathogenic escherichia coli in bladder epithelial cells. J. Funct. Foods 2017, 29, 275-280. [CrossRef]

60. Fayeulle, N.; Vallverdu-Queralt, A.; Meudec, E.; Hue, C.; Boulanger, R.; Cheynier, V.; Sommerer, N. Characterization of new flavan-3-Ol derivatives in fermented cocoa beans. Food Chem. 2018, 259, 207-212. [CrossRef]

61. Khoo, H.E.; Azlan, A.; Tang, S.T.; Lim, S.M. Anthocyanidins and anthocyanins: Colored pigments as food, pharmaceutical ingredients, and the potential health benefits. Food Nutr. Res. 2017, 61, 1361779. [CrossRef]

62. Ali, H.M.; Almagribi, W.; Al-Rashidi, M.N. Antiradical and reductant activities of anthocyanidins and anthocyanins, structureactivity relationship and synthesis. Food Chem. 2016, 194, 1275-1282. [CrossRef]

63. Mudd, A.M.; Gu, T.; Munagala, R.; Jeyabalan, J.; Egilmez, N.K.; Gupta, R.C. Chemoprevention of colorectal cancer by anthocyanidins and mitigation of metabolic shifts induced by dysbiosis of the gut microbiome. Cancer Prev. Res. 2020, 13, 41-51. [CrossRef] [PubMed]

64. Zhang, L.-L.; Lin, Y.-M.; Zhou, H.-C.; Wei, S.-D.; Chen, J.-H. Condensed tannins from mangrove species kandelia candel and rhizophora mangle and their antioxidant activity. Molecules 2010, 15, 420-431. [CrossRef] [PubMed]

65. Smeriglio, A.; Barreca, D.; Bellocco, E.; Trombetta, D. Proanthocyanidins and hydrolysable tannins: Occurrence, dietary intake and pharmacological effects: Pharmacological aspects of tannins. Br. J. Pharmacol. 2017, 174, 1244-1262. [CrossRef] [PubMed]

66. Tie, F.; Wang, J.; Liang, Y.; Zhu, S.; Wang, Z.; Li, G.; Wang, H. Proanthocyanidins ameliorated deficits of lipid metabolism in type 2 diabetes mellitus via inhibiting adipogenesis and improving mitochondrial function. IJMS 2020, 21, 2029. [CrossRef] [PubMed]

67. Ismail, T.; Calcabrini, C.; Diaz, A.; Fimognari, C.; Turrini, E.; Catanzaro, E.; Akhtar, S.; Sestili, P. Ellagitannins in cancer chemoprevention and therapy. Toxins 2016, 8, 151. [CrossRef]

68. Rasines-Perea, Z.; Jacquet, R.; Jourdes, M.; Quideau, S.; Teissedre, P.-L. Ellagitannins and flavano-ellagitannins: Red wines tendency in different areas, barrel origin and ageing time in barrel and bottle. Biomolecules 2019, 9, 316. [CrossRef] [PubMed]

69. Qian, Y.; Gao, G.; Chen, W. Research Progress of concepts and techniques related to post-genome era. J. Suzhou Coll. 2007, 4, 101-103.

70. Chen, J.; Uto, T.; Tanigawa, S.; Kumamoto, T.; Fujii, M.; Hou, D.-X. Expression profiling of genes targeted by bilberry (Vaccinium myrtillus) in macrophages through DNA microarray. Nutr. Cancer 2008, 60, 43-50. [CrossRef]

71. Chen, J.; Qin, S.; Xiao, J.; Tanigawa, S.; Uto, T.; Hashimoto, F.; Fujii, M.; Hou, D.X. A Genome-wide microarray highlights the antiinflammatory genes targeted by oolong tea theasinensin a in macrophages. Nutr. Cancer 2011, 63, 1064-1073. [CrossRef]

72. Verdu, C.F.; Guyot, S.; Childebrand, N.; Bahut, M.; Celton, J.-M.; Gaillard, S.; Lasserre-Zuber, P.; Troggio, M.; Guilet, D.; Laurens, F. QTL analysis and candidate gene mapping for the polyphenol content in cider apple. PLoS ONE 2014, 9, e107103. [CrossRef]

73. Ding, T. The Evaluation of Polyphenol in Peach and Its QTL Mapping. Master's Thesis, Chinese Academy of Agricultural Sciences, Beijing, China, 2017.

74. Tian, J. Genome Mining for the Pentangular Polyphenols. Ph.D. Thesis, Northeast Agricultural University, Harbin, China, 2016.

75. Hou, D.-X.; Luo, D.; Tanigawa, S.; Hashimoto, F.; Uto, T.; Masuzaki, S.; Fujii, M.; Sakata, Y. Prodelphinidin B-4 3'-O-gallate, a tea polyphenol, is involved in the inhibition of COX-2 and INOS via the downregulation of TAK1-NF-KappaB pathway. Biochem. Pharmacol. 2007, 74, 742-751. [CrossRef]

76. Zhang, L.; Li, Y.; Gu, Z.; Wang, Y.; Shi, M.; Ji, Y.; Sun, J.; Xu, X.; Zhang, L.; Jiang, J.; et al. Resveratrol inhibits enterovirus 71 replication and pro-inflammatory cytokine secretion in rhabdosarcoma cells through blocking IKKs/NF-KB signaling pathway. PLoS ONE 2015, 10, e0116879. [CrossRef] [PubMed]

77. Harasstani, O.A.; Moin, S.; Tham, C.L.; Liew, C.Y.; Ismail, N.; Rajajendram, R.; Harith, H.H.; Zakaria, Z.A.; Mohamad, A.S.; Sulaiman, M.R. Flavonoid combinations cause synergistic inhibition of proinflammatory mediator secretion from lipopolysaccharideinduced RAW 264.7 cells. Inflamm. Res. 2010, 59, 711-721. [CrossRef] [PubMed]

78. Woo, K.J. Differential inhibitory effects of baicalein and baicalin on LPS-induced cyclooxygenase-2 expression through inhibition of C/EBPbeta DNA-binding activity. Immunobiology 2006, 211, 359-368. [CrossRef]

79. Kim, B.H.; Lee, I.J.; Lee, H.-Y.; Han, S.-B.; Hong, J.T.; Ahn, B.; Lee, C.-K.; Kim, Y. Quercetin 3-O-beta-(2"-galloyl)-glucopyranoside inhibits endotoxin LPS-induced IL-6 expression and NF-KB activation in macrophages. Cytokine 2007, 39, 207-215. [CrossRef] [PubMed]

80. Tanigawa, S.; Fujii, M.; Hou, D.-X. Action of Nrf2 and keap1 in ARE-mediated NQO1 expression by quercetin. Free Radic. Biol. Med. 2007, 42, 1690-1703. [CrossRef]

81. Hou, D.X.; Fukuda, M.; Johnson, J.A.; Miyamori, K.; Ushikai, M.; Fujii, M. Fisetin induces transcription of NADPH: Quinone oxidoreductase gene through an antioxidant responsive element-involved activation. Int. J. Oncol. 2001, 18, 1175-1179. [PubMed]

82. Hou, D.X.; Fukuda, M.; Fujii, M.; Fuke, Y. Transcriptional regulation of nicotinamide adenine dinucleotide phosphate: Quinone oxidoreductase in murine hepatoma cells by 6-(methylsufinyl)hexyl isothiocyanate, an active principle of wasabi (Eutrema wasabi Maxim). Cancer Lett. 2000, 161, 195-200. [CrossRef] 
83. Altamemi, I.; Murphy, E.A.; Catroppo, J.F.; Zumbrun, E.E.; Zhang, J.; McClellan, J.L.; Singh, U.P.; Nagarkatti, P.S.; Nagarkatti, M. Role of MicroRNAs in resveratrol-mediated mitigation of colitis-associated tumorigenesis in Apc(Min/+) mice. J. Pharmacol. Exp. Ther. 2014, 350, 99-109. [CrossRef]

84. Guodong, R.; Jianguo, Z.; Xiaoxia, L.; Ying, L. Identification of putative genes for polyphenol biosynthesis in olive fruits and leaves using full-length transcriptome sequencing. Food Chem. 2019, 300, 125246. [CrossRef]

85. Valdés, A.; Sullini, G.; Ibáñez, E.; Cifuentes, A.; García-Cañas, V. Rosemary polyphenols induce unfolded protein response and changes in cholesterol metabolism in colon cancer cells. J. Funct. Foods 2015, 15, 429-439. [CrossRef]

86. Figeys, D.; Pinto, D. Proteomics on a chip: Promising developments. Electrophoresis 2001, 22, 208-216. [CrossRef]

87. Díaz-Chávez, J.; Fonseca-Sánchez, M.A.; Arechaga-Ocampo, E.; Flores-Pérez, A.; Palacios-Rodríguez, Y.; Domínguez-Gómez, G.; Marchat, L.A.; Fuentes-Mera, L.; Mendoza-Hernández, G.; Gariglio, P.; et al. Proteomic profiling reveals that resveratrol inhibits HSP27 expression and sensitizes breast cancer cells to doxorubicin therapy. PLoS ONE 2013, 8, e64378. [CrossRef] [PubMed]

88. Zhu, D.-J.; Chen, X.-W.; Wang, J.-Z.; Ju, Y.-L.; Yang, M.-Z.O.; Zhang, W.-J. Proteomic analysis identifies proteins associated with curcumin-enhancing efficacy of irinotecan-induced apoptosis of colorectal cancer LOVO cell. Int. J. Clin. Exp. Pathol. 2014, 7, $1-15$.

89. Xu, R.; Tian, E.; Tang, H.; Liu, C.; Wang, Q. Proteomic analysis of gossypol induces necrosis in multiple myeloma cells. BioMed. Res. Int. 2014, 2014, 839232. [CrossRef]

90. Liu, Z.; Li, Q.; Huang, J.; Liang, Q.; Yan, Y.; Lin, H.; Xiao, W.; Lin, Y.; Zhang, S.; Tan, B.; et al. Proteomic analysis of the inhibitory effect of epigallocatechin gallate on lipid accumulation in human HepG2 cells. Proteome Sci. 2013, 11, 32. [CrossRef]

91. Zhou, J.; Liang, S.; Fang, L.; Chen, L.; Tang, M.; Xu, Y.; Fu, A.; Yang, J.; Wei, Y. Quantitative proteomic analysis of HepG2 cells treated with quercetin suggests IQGAP1 involved in quercetin-induced regulation of cell proliferation and migration. OMICS 2009, 13, 93-103. [CrossRef]

92. Oliver, S. Systematic functional analysis of the yeast genome. Trends Biotechnol. 1998, 16, 373-378. [CrossRef]

93. Liu, P.; Wang, P. Application of metabolomics technology in the research of Chinese medicine. Chin. J. Integr. Med. 2014, 20, 307-310. [CrossRef]

94. Zhou, J.; Tang, L.; Shen, C.-L.; Wang, J.-S. Green tea polyphenols modify gut-microbiota dependent metabolisms of energy, bile constituents and micronutrients in female sprague-dawley rats. J. Nutr. Biochem. 2018, 61, 68-81. [CrossRef]

95. Szekeres, T.; Saiko, P.; Fritzer-Szekeres, M.; Djavan, B.; Jäger, W. Chemopreventive effects of resveratrol and resveratrol derivatives: Chemopreventive effects of resveratrol. Ann. N. Y. Acad. Sci. 2011, 1215, 89-95. [CrossRef] [PubMed]

96. Kim, H.J.; Tsoy, I.; Park, J.M.; Chung, J.I.; Shin, S.C.; Chang, K.C. Anthocyanins from soybean seed coat inhibit the expression of TNF- $\alpha$-induced genes associated with ischemia/reperfusion in endothelial cell by NF-KB-dependent pathway and reduce rat myocardial damages incurred by ischemia and reperfusion in vivo. FEBS Lett. 2006, 580, 1391-1397. [CrossRef] [PubMed]

97. Tang, X. Effects of Tea Polyphenols EGCG on Gut Microbiota and Metabolism in Mice Based on Bioinformatics. Master's Thesis, Nanchang University, Nanchang, China, 2019.

98. Li, Q.; Liang, X.; Guo, N.; Hu, L.; Prasad, M.E.; Wu, Y.; Xue, X.; Wu, L.; Wang, K. Protective effects of bee pollen extract on the caco-2 intestinal barrier dysfunctions induced by dextran sulfate sodium. Biomed. Pharmacother. 2019, 117, 109200. [CrossRef] [PubMed]

99. Xiao, J. Stability of dietary polyphenols: It's never too late to mend? Food Chem. Toxicol. 2018, 119, 3-5. [CrossRef] [PubMed]

100. Sun, J.; Liu, X.; Yang, T.; Slovin, J.; Chen, P. Profiling polyphenols of two diploid strawberry (Fragaria vesca) inbred lines using UHPLC-HRMS(n.). Food Chem. 2014, 146, 289-298. [CrossRef] [PubMed]

101. Grace, M.H.; Xiong, J.; Esposito, D.; Ehlenfeldt, M.; Lila, M.A. Simultaneous LC-MS quantification of anthocyanins and nonanthocyanin phenolics from blueberries with widely divergent profiles and biological activities. Food Chem. 2019, 277, 336-346. [CrossRef]

102. Acero, N.; Gradillas, A.; Beltran, M.; García, A.; Muñoz Mingarro, D. Comparison of phenolic compounds profile and antioxidant properties of different sweet cherry (Prunus avium L.) varieties. Food Chem. 2019, 279, 260-271. [CrossRef]

103. Oszmiański, J.; Kolniak-Ostek, J.; Wojdyło, A. Characterization of phenolic compounds and antioxidant activity of solanum scabrum and solanum burbankii berries. J. Agric. Food Chem. 2014, 62, 1512-1519. [CrossRef] [PubMed]

104. Cavaliere, C.; Foglia, P.; Gubbiotti, R.; Sacchetti, P.; Samperi, R.; Laganà, A. Rapid-resolution liquid chromatography/mass spectrometry for determination and quantitation of polyphenols in grape berries. Rapid Commun. Mass Spectrom. 2008, 22, 3089-3099. [CrossRef]

105. Ma, S.; Kim, C.; Neilson, A.P.; Griffin, L.E.; Peck, G.M.; O’Keefe, S.F.; Stewart, A.C. Comparison of common analytical methods for the quantification of total polyphenols and flavanols in fruit juices and ciders. J. Food Sci. 2019, 84, 2147-2158. [CrossRef]

106. Hossain, M.B.; Lebelle, J.; Birsan, R.; Rai, D.K. Enrichment and assessment of the contributions of the major polyphenols to the total antioxidant activity of onion extracts: A fractionation by flash chromatography approach. Antioxidants 2018, 7, E175. [CrossRef] [PubMed]

107. Olsen, H.; Aaby, K.; Borge, G.I.A. Characterization and quantification of flavonoids and hydroxycinnamic acids in curly kale (Brassica oleracea L. Convar. Acephala Var. Sabellica) by HPLC-DAD-ESI-MSn. J. Agric. Food Chem. 2009, 57, 2816-2825. [CrossRef] [PubMed] 
108. Llorach, R.; Gil-Izquierdo, A.; Ferreres, F.; Tomás-Barberán, F.A. HPLC-DAD-MS/MS ESI characterization of unusual highly glycosylated acylated flavonoids from cauliflower (Brassica oleracea L. Var. Botrytis) agroindustrial byproducts. J. Agric. Food Chem. 2003, 51, 3895-3899. [CrossRef] [PubMed]

109. Ha, T.J.; Lee, M.-H.; Park, C.-H.; Pae, S.-B.; Shim, K.-B.; Ko, J.-M.; Shin, S.-O.; Baek, I.-Y.; Park, K.-Y. Identification and characterization of anthocyanins in yard-long beans (Vigna unguiculata ssp. Sesquipedalis L.) by high-performance liquid chromatography with diode array detection and electrospray ionization/mass spectrometry (HPLC-DAD-ESI/MS) analysis. J. Agric. Food Chem. 2010, 58, 2571-2576. [CrossRef] [PubMed]

110. Rao, S.; Santhakumar, A.B.; Chinkwo, K.; Blanchard, C. Q-TOF LC/MS identification and UHPLC-online ABTS antioxidant activity guided mapping of barley polyphenols. Food Chem. 2018, 266, 323-328. [CrossRef] [PubMed]

111. Bolling, B.W.; Dolnikowski, G.; Blumberg, J.B.; Chen, C. Quantification of almond skin polyphenols by liquid chromatographymass spectrometry. J. Food Sci. 2009, 74, C326-C332. [CrossRef]

112. González-Barrio, R.; Nuñez-Gomez, V.; Cienfuegos-Jovellanos, E.; García-Alonso, F.J.; Periago-Castón, M.J. Improvement of the flavanol profile and the antioxidant capacity of chocolate using a phenolic rich cocoa powder. Foods 2020, 9, E189. [CrossRef]

113. Nzekoue, F.K.; Angeloni, S.; Navarini, L.; Angeloni, C.; Freschi, M.; Hrelia, S.; Vitali, L.A.; Sagratini, G.; Vittori, S.; Caprioli, G. Coffee silverskin extracts: Quantification of 30 bioactive compounds by a new HPLC-MS/MS method and evaluation of their antioxidant and antibacterial activities. Food Res. Int. 2020, 133, 109128. [CrossRef]

114. Zhuang, J.; Dai, X.; Zhu, M.; Zhang, S.; Dai, Q.; Jiang, X.; Liu, Y.; Gao, L.; Xia, T. Evaluation of astringent taste of green tea through mass spectrometry-based targeted metabolic profiling of polyphenols. Food Chem. 2020, 305, 125507. [CrossRef]

115. Vallverdú-Queralt, A.; Boix, N.; Piqué, E.; Gómez-Catalan, J.; Medina-Remon, A.; Sasot, G.; Mercader-Martí, M.; Llobet, J.M.; Lamuela-Raventos, R.M. Identification of phenolic compounds in red wine extract samples and zebrafish embryos by HPLC-ESI-LTQ-orbitrap-MS. Food Chem. 2015, 181, 146-151. [CrossRef]

116. Jian, W.; Cao, H.; Yuan, S.; Liu, Y.; Lu, J.; Lu, W.; Li, N.; Wang, J.; Zou, J.; Tang, N.; et al. SIMYB75, an MYB-type transcription factor, promotes anthocyanin accumulation and enhances volatile aroma production in tomato fruits. Hortic. Res. 2019, 6, 22. [CrossRef] [PubMed]

117. Wei, K.; Wang, L.; Zhang, Y.; Ruan, L.; Li, H.; Wu, L.; Xu, L.; Zhang, C.; Zhou, X.; Cheng, H.; et al. A coupled role for CsMYB75 and CsGSTF1 in anthocyanin hyperaccumulation in purple tea. Plant J. 2019, 97, 825-840. [CrossRef] [PubMed]

118. Wang, P.; Zhang, L.; Jiang, X.; Dai, X.; Xia, T. Evolutionary and functional characterization of leucoanthocyanidin reductases from Camellia sinensis. Planta 2018, 247, 139-154. [CrossRef] [PubMed]

119. Masumoto, S.; Terao, A.; Yamamoto, Y.; Mukai, T.; Miura, T.; Shoji, T. Non-absorbable apple procyanidins prevent obesity associated with gut microbial and metabolomic changes. Sci. Rep. 2016, 6, 31208. [CrossRef]

120. Zhang, Y.; Owusu, L.; Duan, W.; Jiang, T.; Zang, S.; Ahmed, A.; Xin, Y. Anti-metastatic and differential effects on protein expression of epigallocatechin-3-gallate in HCCLM6 hepatocellular carcinoma cells. Int. J. Mol. Med. 2013, 32, 959-964. [CrossRef]

121. Ménoret, A.; Drew, D.A.; Miyamoto, S.; Nakanishi, M.; Vella, A.T.; Rosenberg, D.W. Differential proteomics identifies PDIA3 as a novel chemoprevention target in human colon cancer cells. Mol. Carcinog. 2014, 53, E11-E22. [CrossRef]

122. Luca, S.V.; Macovei, I.; Bujor, A.; Miron, A.; Skalicka-Wozniak, K.; Aprotosoaie, A.C.; Trifan, A. Bioactivity of dietary polyphenols: The role of metabolites. Crit. Rev. Food Sci. Nutr. 2020, 60, 626-659. [CrossRef]

123. Gerritsen, J.; Smidt, H.; Rijkers, G.T.; de Vos, W.M. Intestinal microbiota in human health and disease: The impact of probiotics. Genes Nutr. 2011, 6, 209-240. [CrossRef]

124. Larrosa, M.; Yanez-Gascon, J.M.; Selma, V.M.; Gonzalez-Sarrias, A.; Toti, S.; Ceron, J.J.; Tomas-Barberan, F.; Dolara, P.; Espin, J.C. Effect of a low dose of dietary resveratrol on colon microbiota, inflammation and tissue damage in a DSS-induced colitis rat model. J. Agric. Food Chem. 2009, 57, 2211-2220. [CrossRef]

125. Kim, N.; Kunisawa, J.; Kweon, M.-N.; Ji, G.E.; Kiyono, H. Oral feeding of Bifidobacterium bifidum (BGN4) prevents CD4(+) CD45RB(High) T cell-mediated inflammatory bowel disease by inhibition of disordered T cell activation. Clin. Immunol. 2007, 123, 30-39. [CrossRef]

126. Yuan, X.; Long, Y.; Ji, Z.; Gao, J.; Fu, T.; Yan, M.; Zhang, L.; Su, H.; Zhang, W.; Wen, X.; et al. Green tea liquid consumption alters the human intestinal and oral microbiome. Mol. Nutr. Food Res. 2018, 62, 1800178. [CrossRef] [PubMed]

127. Vendrame, S.; Guglielmetti, S.; Riso, P.; Arioli, S.; Klimis-Zacas, D.; Porrini, M. Six-week consumption of a wild blueberry powder drink increases bifidobacteria in the human gut. J. Agric. Food Chem. 2011, 59, 12815. [CrossRef] [PubMed]

128. Nishida, A.; Inoue, R.; Inatomi, O.; Bamba, S.; Naito, Y.; Andoh, A. Gut microbiota in the pathogenesis of inflammatory bowel disease. Clin. J. Gastroenterol. 2018, 11, 1-10. [CrossRef] [PubMed]

129. Hou, J.; Hu, M.; Zhang, L.; Gao, Y.; Ma, L.; Xu, Q. Dietary taxifolin protects against dextran sulfate sodium-induced colitis via NF-KB signaling, enhancing intestinal barrier and modulating gut microbiota. Front. Immunol. 2020, 11, 631809. [CrossRef] [PubMed]

130. Duda-Chodak, A.; Tarko, T.; Satora, P.; Sroka, P. Interaction of dietary compounds, especially polyphenols, with the intestinal microbiota: A review. Eur. J. Nutr. 2015, 54, 325-341. [CrossRef] [PubMed]

131. Edwards, C.A.; Havlik, J.; Cong, W.; Mullen, W.; Preston, T.; Morrison, D.J.; Combet, E. Polyphenols and health: Interactions between fibre, plant polyphenols and the gut microbiota. Nutr. Bull. 2017, 42, 356-360. [CrossRef] [PubMed]

132. Li, W.; Deng, Y.; Chu, Q.; Zhang, P. Gut microbiome and cancer immunotherapy. Cancer Lett. 2019, 447, 41-47. [CrossRef] 
133. Ma, C.; Han, M.; Heinrich, B.; Fu, Q.; Zhang, Q.; Sandhu, M.; Agdashian, D.; Terabe, M.; Berzofsky, J.A.; Fako, V.; et al. Gut microbiome-mediated bile acid metabolism regulates liver cancer via NKT cells. Science 2018, 360, eaan5931. [CrossRef] [PubMed]

134. Tomás-Barberán, F.A.; Selma, M.V.; Espín, J.C. Interactions of gut microbiota with dietary polyphenols and consequences to human health. Curr. Opin. Clin. Nutr. Metab. Care 2016, 19, 471-476. [CrossRef]

135. De Bruyne, T.; Steenput, B.; Roth, L.; de Meyer, G.R.Y.; Santos, C.N.D.; Valentová, K.; Dambrova, M.; Hermans, N. Dietary Polyphenols targeting arterial stiffness: Interplay of contributing mechanisms and gut microbiome-related metabolism. Nutrients 2019, 11, E578. [CrossRef]

136. Sorrenti, V.; Ali, S.; Mancin, L.; Davinelli, S.; Paoli, A.; Scapagnini, G. Cocoa polyphenols and gut microbiota interplay: Bioavailability, prebiotic effect, and impact on human health. Nutrients 2020, 12, E1908. [CrossRef]

137. Aviram, M.; Rosenblat, M. Pomegranate protection against cardiovascular diseases. Evid. Based Complement. Alternat. Med. 2012, 2012, 382763. [CrossRef] [PubMed]

138. Zhou, J.; Tang, L.; Shen, C.-L.; Wang, J.-S. Green tea polyphenols boost gut-microbiota-dependent mitochondrial TCA and urea cycles in Sprague-Dawley rats. J. Nutr. Biochem. 2020, 81, 108395. [CrossRef] [PubMed]

139. Yang, R.; Shan, S.; Zhang, C.; Shi, J.; Li, H.; Li, Z. Inhibitory effects of bound polyphenol from foxtail millet bran on colitisassociated carcinogenesis by the restoration of gut microbiota in a mice model. J. Agric. Food Chem. 2020, 68, 3506-3517. [CrossRef] [PubMed] 